\title{
The Influence of the County Public Service Board (CPSB), on the Devolved Human Resources Governance in Kenya
}

\author{
Mr. Elijah NjagiIreri \\ $\mathrm{PhD}$. Candidate \\ Governance and Leadership \\ Jomo Kenyatta University \\ Agriculture and Technology (JKUAT) \\ Kenya \\ Dr. Wario Guyo Ph.D. \\ Associate Professor \\ Lecturer \\ Jomo Kenyatta University of Agriculture \\ Technology (JKUAT) Kenya \\ The Director, Nairobi CBD Campus (JKUAT)
}

\begin{abstract}
The Constitution of Kenya passed in 2010 transformed the way the country conducted its public affairs in various ways. The County Public Service Board was one such product under the concept of devolution of services between the national and county government encapsulated in the fourth schedule. Devolution was an important innovation designed to institute accountability, transparency and integrity in the selection, appointment, promotion and removal of public servants through the CPSB. The CPSB, replaced the Public Service Commission (PSC) but discharged its duties at the County level. Its mandate is to select, appoint, promote and remove public servants when the need arose. The CSPB is required to discharge its functions using guidelines encapsulated in Chapter 6, 10 and Article 232 of the Constitution, the Leadership and Integrity Act, the Public Officers Ethics Act and the Ethics and Anti-Corruption Act. These elaborate laws would lead to an efficient and effective human resource at the county level. Instead, the CSPB use criteria far removed from the elaborate mechanism articulated in the Constitution and statute. This is because, the CSPB does not have independence and autonomy in decision making, and instead decisions are made elsewhere using political considerations. This is even despite the existence of moderating factors such as international legal standards on the selection, appointment, promotion and removal of public servants. This paper uses a descriptive and comparative methods to explain the variables that influence the CSPB in the governance of HR at the county level.
\end{abstract}

\section{Introduction and Background}

\section{Introduction}

This study explores how the creation of County Public Service Board (CPSB) under the new Constitution has influenced not only the governance of human resources (HR) but the performance of employees at the county level. The focus of the paper is on the challenges of devolution on HR and how CPSB has addressed these challenges. HR emphasizes the importance of the employees as a valuable asset in achieving sustainable competitive advantage that human resource practices need to be integrated with the corporate strategy, and that HR specialists help organizational controllers to meet both efficiency and equity objectives (Institute of Economic Affairs, 2010). Scholars and practitioners have agreed on the need to move away from a top down command and control model to one that is based on high involvement and reciprocal commitment. This requires that a new kind of psychological contract based on mutual trust between an organization and its employees (IEA, 2010). Devolution is one of the core transformative features of the Constitution of Kenya 2010. 
Devolution of power and resources to the communities is being pursued throughout the globe with emphasis on local economic development, good governance, local democracy and citizen participation (Partnership for Transformational Devolution, 2017). Devolution of power and resources is a pivotal means of promoting and advancing democracy, participation and accountability. It enhances local development, and efficient and effective service delivery. It would also entrench equity and inclusiveness in development and access to services. Lastly, devolution is enhancing localized good governance by incorporating vertical separation of powers accountability and increasing the ambit of checks and balances. The Constitution of Kenya introduced major changes in governance with a clear shift from a highly centralized to a decentralized system (Article, 174). Devolution, as envisaged in the Constitution of Kenya is based on sharing of political, administrative and fiscal responsibilities between the national and county governments. Human resource was not an exception of the resources devolved. With a number of studies reporting positive outcomes of devolution of HR function, there are equally numerous inherent problems within the framework of devolution that can seriously undermine the positive outcomes reported.

\section{Definition of Terms}

Accountability, Competence, Corporate governance, County, County public service,County Public Service Board, Devolution, Good governance, Human resource devolution, Integrity, Performance, .Transparency.

\subsection{Background}

This section contextualizes the creation of the CPSB and how it has influenced the appointment, promotion confirmation and removal of human resources at the county level. Before 2010, the public service was regulated under one body known as the Public Service Commission (PSC) (Section 106, Constitution of Kenya, 1963 (amended). All members of the PSC were appointed by the President as part of the exercise of his executive power (Section 106(2), Constitution of Kenya, 1963 (amended). The powers of the commission were outlined in section 107(1) as the appointment of persons to hold or act in offices in the public service and in the service of local authorities (including the power to confirm appointments), the power to exercise disciplinary control over persons holding or acting in those offices and the power to remove those persons from office. Whereas this was the legal provision, indeed all persons who served in the public service did so at the pleasure of the President (Section 24(1), Constitution of Kenya, 1963 (amended). This meant that the President could appoint any person, create offices and remove persons from office without reference to any person or institution.

The promulgation of Constitution of Kenya 2010, brought with it significant reforms in the governance of human resources in the public sector especially at the county government level. The constitution and human resources in particular were under pinned by certain principles namely devolution, public participation, integrity, accountability, transparency and gender equality. The principle of devolution is enshrined in chapter 11 of the Constitution which involves getting services closer to the people from a centralized system of government to a decentralized one including that of human resources. Devolution of the human resources is provided in Article 235 of the Constitution read together with the County Government Act 2012 (Part VII, the County Government Act 2012). Under this framework, each of the 47 counties created a CPSB (Section 57, the County Government Act 2012). The functions of the previous PSC were effectively taken over the CPSB as to the establishment (Section 60, the County Government Act 2012) and abolishment of offices (Section 61-62, the County Government Act 2012), all appointments, confirmations, promotion, discipline and removal if and when it becomes necessary are all done by the CPSB at the county level.

The Constitution further empowers Parliament to establish legislation that would implement these reforms in Article 235. The County Government Act was enacted in 2012, to among other things give effect to Chapter Eleven of the Constitution; to provide for county governments' powers, functions and responsibilities to deliver services and for connected purposes (Preamble, County Government Act, 2012). The most important provision of this legislation is the creation of the CPSB with powers to appoint, promote, confirm and dismiss employees of the county government. Appointment to public service is further subject to other guidelines provided in Chapter Six of the Constitution on leadership and integrity, Principles of public service and Article 232 which emphasizes competence qualifications for employment. All appointments are done in an atmosphere of public participation, equality, nondiscrimination, gender equality, inclusivity in the letter and spirit of the Constitution. These are the principles upon which the influence of CPSB would be discussed and measured. 


\section{Literature Review}

\section{Introduction}

This paper will use the following in analyzing literature: the theoretical review, empirical review and conceptual framework guided by: selection, appointment procedures, promotion, dismissal of the human resource at the county level.

\subsection{Theoretical Framework}

A number of theories have been proposed that influence of the CPSB on the human resource in the county. Some of the theories in consideration include: the agency theory, stakeholder theory, the human capital theory, the equity theory and the managerial theory.

\subsubsection{Stakeholder Theory}

The stake holder theory was propounded by Edward Friedman who addressed the two most important individuals in a corporate entity: the investor and the stakeholder (Friedman, 1984). The starting point of this theory is that corporate entities are not just formed to maximize profit but serve a broader constituency known as stakeholders in addition to the traditional investors (Gibson, 2000). Accordingly the success or failure of a corporate entity depends on how much value is given to the stakeholder who comprises: creditors, employees, the community, the government and the environment (Mulili, 2011). Thus a board has both a moral and legal obligation to ensure is properly involved in all aspects of decision making (Dunphy\& Benn, 2003). Only then would such a corporation succeed through a process of public participation (Manville, 2003). The stakeholder theory seems to have informed and influenced the contents of Kenya's Constitution especially Article 20(1) of the Bill of Rights which applies to all law and binds all State organs and all persons. It establishes a broad based regime for the protection of human rights for individuals and corporate entities. Chapter 6 of the Constitution of Kenya, 2010, provides for public participation in all aspects of decision making. The theory is also evident in article dealing with regional balance, gender equality and affirmative action. This is affirmed in article 73 of the Constitution which enshrines affirmative measures in the governance of State Corporations which shall acknowledge and represent the diversity of Kenya and adequate and equal opportunity for appointment, training and advancement at all levels of the public service of men and women; the members of all ethnic groups; the youth and persons with disability (Article 232(1h,I), Constitution of Kenya, 2010). The duty of the board is to align its interests to those of the stakeholder. Failure to do so leads to corporate collapse as was illustrated by the Enron and Worldcom cases (Kaptein\& Van Tulder, 2003).

\subsubsection{The Agency Theory}

The agency theory was developed by Berle and Means who argued that parties in a contractual relationship have conflicting and different goals and visions from each other (Berleand Means). He asserts that corporate entities are made up of a conglomeration of contracts between the owner (principal) on the one hand and the shareholder (agent) on the other. Owners hand over decision making powers to agents entrusted to perform these functions on their behalf (Fama and Jensen 1983). This relationship is not always smooth as the principal/agent model creates tension described by Jensen as "the desire or goal of the principal and agent conflict, and it is difficult or expensive for the principal to verify what the agent is actually doing [or that] the agent has behaved appropriately" (Fama and Jensen 1983) Tension arises because both have completely different motivations, the principal wishes to maximize on his/her investment while the agent, the firm not being his has the desire to satisfy personal interests. The principal has little capacity of verifying the intentions of the agent due to information asymmetry (the agent has more information about the firm than the principal) (Fama and Jensen 1983). Thus corporate entities suffer from adverse selection and moral hazard which a fixed remuneration is unlikely to cure. The best option would therefore be remuneration that is based on performance.

In the context of County governments, the citizens are the principals who have delegated decision making with regard to selection, appointments, promotion and even removal of county employees to County boards. The citizen's desire is that those appointed would be diligent in discharging their mandate. Since they have little information about the internal workings of the firm, they have no mechanism of knowing the intentions of the board that are most probably driven by self-interest purposely to satisfy individual needs before attending to public ones. This partly explains why CPSB is riddled with corruption, nepotism, tribalism, clanism and political patronage in the discharge of their official mandate. 
The agency theory was conceptualized based on a number of assumptions: that the board would be a homogeneous group of likeminded persons whose sole interest would be loyalty to the corporation for the benefit of the shareholders. Second, that the owner/principal would be identifiable persons or an individual. In the case of county boards, the principal is composed of hundreds of thousands or millions with diverse interests pegged on service delivery. In Kenya, many people are not aware of how counties are run or should be run and care less whether corporate governance practices are adhered to or not. Due to information asymmetry many of them are likely to be misled and misinformed by the board for personal reasons of self-preservation. Without an effective mechanism of directly holding the board accountable other than through a national election and only if the county assembly opts to appoint a new board, citizens are not able to ensure that the board only performs that which is in their best interest.

\subsubsection{The Human Capital Theory}

Human capital refers to the stored valued knowledge or skills of members of the workforce in an enterprise (Zima, 2007). The agreement among scholars is that human capital is important to the formation and growth of entrepreneurial ventures (Zima, 2007). Human capital is referred in terms of the time, experience, knowledge and abilities of an individual which can be used in the production process in an ongoing concern (Guest, 2002). Human capital theory proposes that the level of education, area of training, previous entrepreneurial experience and business skills influence the growth of the enterprise (Guest, 2002). Human capital is considered as the skills and training an entrepreneur acquires, such as apprenticeship, work experience, and training in various skills. The objective of the study was to investigate how human resource management functions affect the growth more specifically on selection, appointment, promotion and dismissal of county government staff which are pertinent to devolved government. This theory is therefore suitable for selection process as it outlines the benefits of time, experience, knowledge and abilities of an individual which can be used in the production process in an ongoing concern.

\subsubsection{The Equity Theory}

The equity theory views the organization's policies and procedures and their fair application, declaring that it influences the employee's level of motivation. According to the theory if rewards and punishments are accorded correctly, employees feel that the company is fair. Equity should not be confused with equality, which means giving everyone the same treatment (Armstrong,, 2006), give friends, other co-workers, peers, counterparts in other organizations or neighbors as the referent that an employee may choose to compare their experience or situation with. Distributive justice, which is ensuring equitable allocation of rewards and penalties, is important to employee motivation and involves a system that deals fairly salaries, bonuses, leave time, working hours, promotions, transfers, dismissals, training, demotions and salary raises (Kenya National Commission on Human Rights, 2009).

Distributive justice which the equity theory focused on has developed into organizational justice, which centers on the overall perception of fairness in the workplace by incorporating what the individual employee perceives as fair (Kenya National Commission on Human Rights, 2009). The procedure used by the organization to grant the reward or penalty as well as the delivery of the reward/penalty as far as retaining the employee's dignity and respect is concerned. This theory is therefore suitable as it describes the importance of a fair reward system that influences employees 'performance in any organization.

\subsubsection{Managerial Theory}

Contrary to popular thought, the managerial theory views boards as legal fictions that are ineffective with no real powers (Cornforth, 2001: 13-15). Whereas shareholders are supposed to be owners of the corporation, the real power belongs to managers who make decisions on behalf of the board. Under this framework the role of the board is to rubber stamp decisions that have been made by the management and in the process give legitimacy by endorsing those decisions (Cornforth, 2001: 13-15). This theory is applicable in this study because boards being appointed by the county governments would only endorse that which has been decided elsewhere mainly by politicians. Such boards therefore do not have any powers to perform their mandate other than rather stamp decisions made by the executive arm of the county.

\subsection{Critique of the Theories}

The theories presented above try to explain why CPSB have been unable to establish effective and efficient boards for better performance of county public service. 
According to the theories, good corporate governance is based on a number of assumptions that are not necessarily found in state or public entities. For example, they are naive in assuming that the only requirements for selection for employment, promotion and even dismissal are based on skills, competence and experience.

In Kenya and in the public sector in particular this is not necessarily the case. Other requirements that are even protected by the Constitution include regional balance, gender sensitivity and inclusiveness. Besides, appointments in counties are linked to political considerations since every incoming governor makes appointments that would fulfill his/her agenda while firing those of the predecessor.

Other assumptions include theories addressing corporate entities that are for profit but not those designed as state entities where the element of profit is less prominent in favor of service delivery in an effective and efficient manner. Theories assume that all that is needed is a knowledgeable shareholder to effect changes; however citizens are generally ignorant of how cpsb boards operate. This is made worse by the assumption that county public service boards have unlimited powers to run devolved human resource as they wish. The reality is real power rests with the political leadership.

\subsection{The Conceptual Framework}

The performance of the human resource at the county level would depend on how county governments would deal with the issues of competence in the selection, appointment and promotion and dismissal of staff. This means that only persons with the right qualifications and experience are appointed. Those appointed should be persons of integrity in a process that is transparent and accountable as the guiding principles. The conceptual framework below depicts the relationships between independent and dependent variables that could be mitigated by certain factors such as: international and national standards on public service and corporate governance codes such as Mwongozo.

\subsection{Empirical Review}

This section reviews researches related to the study variables will be to find out what other scholars have discussed about them. Through this, the potential gaps to be filled by this study will be identified.

\subsubsection{The Concept of Devolving Human Resource}

The human resource is the life blood of any organization and despite the application of technology in modern organizations, human resource is still relevant and the most adaptive resource in any organization. The strategic value of HR stems from the fact that, apart from other resources of production like land, capital and technology, the human resource is endowed with discretionary decision-making power with a competitive advantage over other resources. Besides, HR combines other resources in the right mix to formulate appropriate strategies for the accomplishment of the desired objectives of the organizational structure. This essential attribute of HR assist any organization in making the right decisions by responding effectively to threats and opportunities within the organization's environment. Thus the organization depends highly on its HR for success and survival. This dependence continuously increases considering the complex and turbulent nature of modern organizations (Maryhofer and Brewster, 2005).

Managing HR at whatever level is complex and problematic because the individuals (workers) hardly adapt or voluntarily embrace the objectives of the organization. As individuals, employees have needs, aspirations, motivations, desires and interests which influence their behavior at work but unfortunately these objectives are sometimes in conflict with the overall objectives of the enterprise. In reconciling this conflicting interests HR management and planning are useful tools employed in harmonizing the needs of the employees with the goals and objectives of the organization on a continuous basis. New kinds of technical knowledge, skills and abilities would require HR practitioners in future who are flexible and willing to deal with the ever accelerating pace and often unpredictable changes in the global workplace (Maryhofer and Brewster, 2005).

Managers in this century have an urgent need to manage change in a speedily and efficient in line with HR context and appropriate competencies. Issues like international HRM, diversity, employment equity, reputation management and corporate ethics amongst others must be factored regarding future identification of HR professionalse role and capabilities. Bhagwatti, J. (2004) clearly states that the forces of global change are at work in organizations and are bound to significantly influence the future of the HR profession.

People are the most valuable assets "is a cliché which no member of any senior management would disagree with. Yet reality for many organizations is that their employees remain undervalued, undertrained and underutilized. Good human resource management strategies make a lot of difference in the output of the employees. 
Human resource management involves managing people in an organization. The last few decades have seen some drastic changes in the strategies employed by various organizations for this purpose. Earlier, it had limited functions confined to paperwork related to hiring and payment of the staff in the organization. Now, it is understood that the most valuable resource of any establishment are its employees, as they play a crucial role in accomplishment of the aims and objectives of a business. Therefore, the focus of human resource management is to deal with the manpower and all the decisions related to it that can have an impact on the productivity. Human Resources refer to worker with different skills, qualification, ambition, managerial talents and so on either in an organization. Devolution of power and resources is a pivotal means of promoting and advancing democracy, participation and accountability. It enhances local development, and efficient and effective service delivery. It would also entrench equity and inclusiveness in development and access to services. Lastly, devolution is enhancing localized good governance by incorporating vertical separation of powers accountability and increasing the ambit of checks and balances (Partnership for Transformational Devolution, 2017). According to Olowu (2001), the primary aim of devolution is empowerment. It also the most extensive type of decentralization (Paulos, 2007). It is intended to reduce the gap between the government, the local population and increase control and direction over utilization of resources and ensure effective and efficient service delivery (Paulos, 2007). In terms of effectiveness and efficiency, "the development performance of local government is more often than not affected by the financial and human resource available to them"' (Adamolekun, 1999).

Devolution improves the HRM functions by placing a greater degree of authority and answerability in the hands of managers at the department and regional Level (Adamolekun, 1999). It is a tool, which will ensure that the civil service has capacity to do the HRM tasks in an effective and efficient way by giving them the power to recruit and select, to promote, to train and to reward accordingly in appropriate manner (Adamolekun, 1999). Analyzing devolution will help us to understand the administrative, political, fiscal and geographical aspects of decentralization. Hence, this study views decentralization as devolution or the transfer of decision-making power and authority from the center to local entities, which have officially demarcated geographic and functional realm in this case from national government to the county governments.

The realization of the promises of devolution would generally depend on a number of factors like clearly defined and demarcated roles and functions of governments at the national and sub-national levels accompanied with a seamless transition process, the political will by the center to decentralize power and resources. It would also depend on strong institutional and human resource capacities of County governments, financial independence and probity of county governments. Much more important would be a well-informed public and organized civil society including media that is robustly engaged in governance and development processes and holding government to account (PTD, 2017: 1).

\subsubsection{The influence of Competence in the selection, appointment, promotion and dismissal of Human Resource on the performance of County Public Service Board (CPSB) in Kenya.}

A study done in the South Africa (Cape Province) evaluated and measured the effectiveness of recruitment and selection and its impact on service delivery amongst staff within the Department of Economic Development and Tourism in the Provincial Government of the Western Cape (Moncarz, \& Kay, 2009). Questionnaires were used to collect and analyze data from a sample size of 121 (Moncarz, \& Kay, 2009). The conclusion was that the guiding principles for the recruitment and selection policy for the department should be adhered to. It was proposed that a toolkit be developed to provide guidance on the management of recruitment and selection process. The researcher suggested that mechanisms should be devised to ensure that the staff remains motivated to achieve excellent service delivery and that professionalism of staff at the department should be recognized. He further lays emphasis on the recruitment for diversity since it encourages creativity and expanded customer base and illustrates that employers who wish to develop a diverse workforce should ensure that it generates applications from a variety of individuals. An advice is also given on the hiring of relatives as this may compromise on the work since if relatives have to work in one department with one supervising the other issues of favoritism will inevitably emerge (Moncarz, \& Kay, 2009).

The Management consultant MCKinsey and Company (1997) investigated the challenges facing businesses in recruiting top talent in its 1997 survey tagged the war of talent (Nankervis, \& Mc Carthy, 1999). The research that surveyed 6,900 managers at 56 large and 11 medium sized organizations in the USA found out that 89\% though it more difficult to attract talented people in 2000 than it had been before, $90 \%$ thought it more difficult to retain them and only $7 \%$ strongly agreed their companies had enough talented managers. 
This only displays how organizations need to be very careful with the process since its only through this that the organization will have the right start to the direction in its quest for attaining its goals and aspirations (Nankervis, \& Mc Carthy, 1999).

2.4.3. The influence of Transparency, Accountability, Integrity in the selection, appointment, promotion and dismissal of Human Resource on the performance of County Public Service Board (CPSB) in Kenya.

According to the Chartered Institute of Public Finance and Accountancy, the aim of good governance in the public sector is to encourage better service delivery and improved accountability by establishing a benchmark for good governance in the public sector (Chartered Institute of Public Finance and Accountancy, 2013: 7). According to the International Federation of Accountants, transparency connotes openness about the outcomes a public sector entity is pursuing, the resources necessary or used, and the performance achieved. Accountability is the obligation of public sector entities to the citizens and other stakeholders to account, and be answerable, for their policies, decisions, and actions, particularly in relation to public finances. Integrity on the other hand is being straightforward and honest in all of one's actions (Chartered Institute of Public Finance and Accountancy, 2013: 7).

The public sector plays a critical role in national economy while public expenditure forms a significant part of gross domestic product (GDP) and public sector entities are substantial employers and major capital market participants (IFAC Public Sector Committee, 2001). The public sector determines, usually through a political process, the outcomes it wants to achieve and the different types of intervention using its human resource. These include enacting legislation or regulations, delivering goods and services, redistributing income through mechanisms such as taxation or social security payments; and the ownership of assets or entities, such as state owned enterprises. Governments also have a role in promoting fairness, peace and order, and sound international relations (IFAC Public Sector Committee, 2001).

Effective governance in the public sector encourages better decision making and the efficient use of resources and strengthens accountability for the stewardship of those resources. Effective governance is characterized by robust scrutiny, which provides important pressures for improving public sector performance and tackling corruption. Effective governance can improve management, leading to more effective implementation of the chosen interventions, better service delivery, and, ultimately, better outcomes. People's lives are thereby improved (IFAC Public Sector Committee, 2001).

\subsection{Summary of the Reviewed Literature}

The reviewed literature shows that a number of issues still need to be addressed before human resource functions are successfully devolved. These includes: competence, integrity, transparency, accountability. In countries where devolution has failed, the reasons advanced have been linked to lack of adequate financial resources to the devolved units to carry out the human resource function. As a consequence devolution on its own is unlikely to improve service delivery to the counties unless the functions are accompanied by funding. A number of studies have suggested that gaps in transparency and accountability at the local level limit the effectiveness of employees. In majority of developing countries, the selection and appointment processes are undermined by political considerations far removed from competence based models.

These constraints have however not been overshadowed by available opportunities to effective human resource devolution brought about by the new Constitution. Studies show that many countries have a rigid civil service appointment structure with wage ceilings while others are contemplating downsizing the workforce. Some counties in Kenya have gone ahead and reduce staff considered to have been employed irregularly. Constraints like these limit the ability of the county to improve performance of human resource through devolution. Implementing agencies such as the Ministry of Devolution need to take advantage of available opportunities in the implementation of devolution. This would facilitate the process of bringing clarity and consistency in the objectives and responsibilities of a devolved human resource function. It would further reduce conflicts and apparent confusion in the lines of authority as a major challenge to effective devolution of human resources.

\subsection{Data Collection Procedures}

Permission wasbe sought from County Governments in Kenya for purposes of undertaking the research study. A letter of consent would be given to the participants, explaining the nature of the research as well as what would be required of them. Questionnaires would be administered on the entire sample through personal delivery. 
The researchers would use telephone calls and personal visits to follow up on the respondents to ensure that the questionnaires are completed. The research assistants would then pick up the completed questionnaires. The researcher would also rely on desktop analysis of secondary data found in the libraries such as review of various books, scholarly journals and articles, reports, internet and publications on the subject matter and related topics.

\subsection{Data Analysis and Presentation}

Data analysis is a process in which raw data is ordered and organized so that useful information can be extracted from it. The process of organizing and thinking about data is a key to understanding what the data does and does not contain. Summarizing data is often critical to supporting arguments made with that data, as is presenting the data in a clear and understandable way. Data collected was analyzed by descriptive analysis. According to Myers (2005), the descriptive statistical tool helped the researcher to describe the data and determine the extent to be used (Myers (2005). The findings were then presented using tables. Data was analyzed through the use of Statistical Package for Social Sciences (SPSS) software due to its ability to analyze with ease management attitudes. The findings that emerged from the analysis were used to compile the report.

\subsection{Results and discussion}

\subsection{Demographic Findings}

The characteristics of the respondents gathered by the study are reported in table 2.1. A sample size of 80 respondents was selected for this study. The sample consisted of $61 \%$ males and $39 \%$ females. The dominant gender being males as they are more involved in employments in Kenya. The frequency of age group among respondents was $5 \%$ between the age of 18-25 years, $39 \%$ between the age of $26-35$ years, $31 \%$ between the age of 36-40 years and $24 \%$ above 40 years. The frequency of current employment among the study respondents was $50 \%$ were on Permanent and Pensionable terms of work, $38 \%$ were on fixed term contract employee terms of work and $13 \%$ were on temporary Terms. The frequency of experience of the study respondents indicates that majority $43 \%$ had between 8-10 years of working experience. 19\% had working experience above 10 years, another 19\% had working experience between 3 to 4 years, 11\% had a working experience between 5 to 7 years and $9 \%$ had a working experience of less than 2 years. The study respondent's distribution of the education level was as follows. $38 \%$ had diploma, 34\% had undergraduate degree, $16 \%$ has post graduate qualifications and $13 \%$ had certificates. This implied that the respondents were knowledgeable and therefore would give valid answers on the effect of competency and transparency in selection, appointment, promotion and dismissal on performance of CPSB

Table 2.1 Demographics

\begin{tabular}{|l|l|l|l|}
\hline \multirow{3}{*}{ Gender } & Factor Levels & Frequency & Percentage \\
\hline \multirow{5}{*}{ Age group in years } & Male & 49 & 61 \\
\cline { 2 - 4 } & Female & 31 & 39 \\
\hline \multirow{5}{*}{ Current employment } & $18-25$ & 5 & 6 \\
\cline { 2 - 4 } & $26-35$ & 31 & 39 \\
\cline { 2 - 4 } & $36-40$ & 25 & 31 \\
\cline { 2 - 4 } & Above 40 & 19 & 24 \\
\hline Years of working & Permanent and Pensionable & 40 & 50 \\
\cline { 2 - 4 } & Fixed Term Contract Employee & 30 & 38 \\
\cline { 2 - 4 } & Temporary Terms & 10 & 13 \\
\hline \multirow{5}{*}{ Education level } & 1 to 2 & 7 & 9 \\
\cline { 2 - 4 } & 3 to 4 & 15 & 19 \\
\cline { 2 - 4 } & 5 to 7 & 9 & 11 \\
\cline { 2 - 4 } & 8 to 10 & 34 & 43 \\
\cline { 2 - 4 } & Above 10 & 15 & 19 \\
\cline { 2 - 4 } & Certificate & 10 & 13 \\
\cline { 2 - 4 } & Diploma & 30 & 38 \\
\cline { 2 - 4 } & Undergraduate Degree & 27 & 34 \\
\cline { 2 - 4 } & Post graduate (Masters and PHD) & 13 & 16 \\
\hline
\end{tabular}

\subsection{Descriptive analysis of study variables}

The normality of the study variables was tested using skewness and kurtosis. All of these values of skewness and kurtosis indices for all the variables did not exceed the absolute values of 1 and, therefore, the data set was 148 
considered to follow normal distribution and consequently the relationship would be tested using multiple linear regression. The internal consistency of the items of the variables was assessed using Cronbach's Alpha. The Cronbach's Alpha values for performance of CPSB, Competency and transparency were, 0.927, 0.957 and 0.795 respectively indicating good subscale reliability as indicated in table 2.2 . The composite index of Performance of CPSB had a mean of 4.05 and a standard deviation of 1.815. The composite index of competency in selection, appointment, promotion dismissal had a mean of 4.16 and a standard deviation of 1.304. The composite index of transparency, accountability and integrity in selection, appointment, promotion and dismissal had a mean of 4.02 and a standard deviation of 1.499. The variables had low values of standard deviation indicating that the respondents gave almost the same responses.

Table 2.2 Descriptive Statistics of study variables

\begin{tabular}{|l|l|l|l|l|l|}
\hline Variable & Mean & Std.dev & Skewness & Kurtosis & Cronbach's Alpha \\
\hline Performance of CPSB & 4.05 & 1.815 & .116 & -.119 & 0.927 \\
\hline Competency & 4.16 & 1.304 & -.522 & .235 & 0.957 \\
\hline Transparency & 4.02 & 1.499 & .027 & .913 & 0.795 \\
\hline
\end{tabular}

\section{Pearson Correlation analysis}

The correlation coefficient between competency in Selection, Appointment, Promotion Dismissal and Performance of CPSB was positive and significant $(\mathrm{r}=0.486, \mathrm{p}$-value $<0.05)$. This shows that higher competency in selection, appointment, promotion and dismissal results in higher Performance of CPSB. The correlation coefficient between Transparency, accountability and integrity in Selection, Appointment, Promotion, Dismissal and Performance of CPSB was positive and significant $(\mathrm{r}=0.712, \mathrm{p}$-value $<0.05)$. This shows that the more the Transparency, accountability and integrity in selection, appointment, promotion and dismissal results in higher Performance of CPSB as indicated in table 4.3.

Table 2.3 Correlation analysis for study variables

\begin{tabular}{|l|l|l|l|}
\hline & Statistics & Competency & Transparency, accountability and integrity \\
\hline Performance of CPSB & Pearson Correlation & $.486^{* *}$ & $.712^{* * *}$ \\
\cline { 2 - 4 } & Sig. (2-tailed) & .000 & .000 \\
\cline { 2 - 4 } & $\mathrm{N}$ & 80 & 80 \\
\hline
\end{tabular}

\section{Regression analysis}

The summary of regression model results and the model fit f-value from ANOVA table are presented in table 2.4. The $\mathrm{R}^{2}$ which measures the explanatory power of the independent variables (Competency and Transparency, accountability and integrity in Selection, Appointment, Promotion, and Dismissal) on Performance of CPSB was 0.518. This implies that $51.8 \%$ of the variation in the Performance of CPSB is explained jointly by Competency and Transparency, accountability and integrity in Selection, Appointment, Promotion, and Dismissal The remaining $49.2 \%$ of the variation in the dependent variable unexplained by this predictors model but by other factors not included in the model. The model from table 4.5 becomes

$$
\text { Performance of CPSB }=0.207+0.493_{\text {Competence }}+0.601_{\text {Transparency }}+\varepsilon
$$

The overall model was a good fit since $(\mathrm{F}$-value $=17.28$ and $\mathrm{p}<0.05)$. This implies that the joint effect of competency and transparency, accountability and integrity in Selection, Appointment, Promotion, and Dismissal had a significant effect on Performance of CPSB. The study investigated multicollinearity assumption which tests whether the two independent variables were highly correlated or not. Variance inflated factor (VIF) was used in testing for multicollinearity. The study results indicate that multicollinearity was not present as the VIF values were less than the threshold 3.

\begin{tabular}{|l|l|l|l|l|}
\hline \multicolumn{5}{|c|}{ Table 2.4 Model Summary, multicollinearity and fitness } \\
\hline Model & R & R Square & Adjusted R Square & Std. Error of the Estimate \\
\hline 1 & $.723^{\text {a }}$ & .518 & .486 & .21035372 \\
\hline Model fitness & $\boldsymbol{F}$ value & P value & Predictor & VIF \\
\hline & $\mathbf{1 7 . 2 8}$ & $\mathbf{0 . 0 0 0}$ & Competency & 1.689 \\
\hline & & Transparency & 1.738 \\
\hline \multicolumn{7}{|l}{ a. Predictors: (Constant), Performance of CPSB } \\
\hline
\end{tabular}


The study further determined the beta coefficients of the independent variable in the regression model. The coefficient of competency in Selection, Appointment, Promotion Dismissal was significant and positive $(\beta=0.493$ and $\mathrm{p}<0.05)$. This implied that a unit increase in the measure of competency in Selection, Appointment, promotion and dismissal leads to a 0.493 units increase in the measure of Performance of CPSB. The coefficient of transparency, accountability and integrity in selection, appointment, promotion and dismissal was found to be significant and positive $(\beta=0.601$ and $\mathrm{p}<0.05)$. This implied that a unit increase in the measure of transparency, accountability and integrity in selection, appointment, promotion and dismissal leads to a 0.601 units increase in the measure of Performance of CPSB. The study also revealed that transparency, accountability and integrity in selection, appointment, promotion and dismissal was the most influencial predictor (Beta $=0.711$ ) followed by competency in Selection, Appointment, promotion and dismissal (Beta $=0.525)$ as indicated in table 4.5.

Table 2.5 multiple linear Regression estimates

\begin{tabular}{|l|l|l|l|l|l|}
\hline Variable & $\begin{array}{l}\text { Unstandardized } \\
\text { Coefficient }\end{array}$ & $\begin{array}{l}\text { Standardized } \\
\text { Coefficient }\end{array}$ & Standard Error & T- Statistic & P- Value \\
\hline Constant & 0.207 & & 0.102 & 2.029 & 0.046 \\
\hline Competency & 0.493 & 0.525 & 0.217 & 2.272 & 0.026 \\
\hline Transparency & 0.601 & 0.711 & 0.231 & 2.602 & 0.011 \\
\hline
\end{tabular}

Dependent Variable $=$ Performance of CPSB

\subsection{Conclusion and Findings}

The requirements for selection for selection, appointment, promotion and even dismissal are based on , competence and in a transparent accountable and with persons with integrity by the county public service boards n Kenya and in the public sector in particular this is not necessarily the case. Other requirements are protected by the Constitution include regional balance, gender sensitivity and inclusiveness. Besides, appointments in counties are linked to political considerations since every incoming governor makes appointments that would fulfill his/her agenda while firing those of the predecessor. One face of the mandate of the mandate of the county public service boards have unlimited powers to run devolved human resource as they wish. The reality is real power rests with the political leadership.

The study recommends that all the County Public Service Boards in Kenya should develop effective mechanisms to enforce the Human Resource Governance in the Kenya especially on selection, appointment, promotion and dismissal of county employees and further subject to other guidelines provided in Chapter Six of the Constitution on leadership and integrity, Principles of public service and Article 232 which emphasizes competence qualifications for employment. All appointments are done in an atmosphere of public participation, equality, nondiscrimination, gender equality, inclusivity in the letter and spirit of the Constitution. These are the principles upon which the influence of CPSB would be felt in devolved Human Resource Governance in Kenya.

\subsection{References}

Adamolekun, L. (1999). Public Administration in Africa, Colorado: West view Press.

Armstrong, M. (2006). A Handbook of Human Resource Management Practice (10th Ed.). London: Kogan Page Press.

Babbie, R. (2004). The Basics of Communication Research. New York: Wadsworth/Thomson Press.

Bhagwatti, J. (2004). In Defense of Globalization, N.Y, Oxford Univ. Press. Chartered Institute of Public Finance and Accountancy, Good Governance in the Public Sector: Consultation Draft for an International Framework (CIPFA: London, 2013).

The Constitution of Kenya, 2010

Cooper, D., \& Schinder, P. (2003). Business Research Methods. (10th Ed). New York: Mc-Graw Hill Press.

The County Government Act, 2012

Guest, D. (2002). Human Resource Management, Corporate Performance and Employee

Wellbeing: Building the Worker into HRM. The Journal of Industrial Relations, Vol. 44 (3), 335-358.

Institute of Economic Affairs, The Dynamic and Trends of Employment in Kenya (IEA-Press: Nairobi, 2010).

IFAC Public Sector Committee (2001), Governance in the Public Sector: A Governing Body Perspective. 
Kenya National Commission on Human Rights (2006). Enhancing and Operationalizing Economic, Social and Cultural Rights in Constitution of Kenya, Position Paper, 9.

Kothari, C. (2004). Research Methodology: Methods and Techniques, (2ndedition). New Delhi: New Age Publication.

Kothari, C. (2008). Research Methodology: Methods and Techniques, (2ndedition). New Delhi: New Age Publication.

Maryhofer, W. and Brewster, C. (2005). "European Human Resource Management Re-searching Developments over Time", The International Review of Management Studies 16(1).

Meyer, J. (2005). Research Methods in the Social Sciences. London: Sage Printers.

Moncarz, E., Zhao, J., \& Kay, C. (2009). An Exploratory Study of US Lodging Properties Organizational Practices on Employee Turnover and Retention.International Journal of Contemporary Hospitality Management, 21(4), 437-458.

Mugenda, M., \&Mugenda, G. (2003).Research Methods: Quantitative and Qualitative Approaches. Nairobi: Laba Publishers.

Nankervis, C., \& Mc Carthy, G. (1999). The Effects of Human Resource Management Practices on Productivity. New York: Working paper, Columbia University Graduate School of Business.

Office of the President, Mwongozo: the Code of Governance for State Corporations (The State Corporations Advisory Committee: Nairobi, 2015).

Olowu, B. (2001). African Decentralization Policies and Practices from 1980 and beyond. The Hague: Working paper Series No.334; Institute of Social Studies.

Orodho, J. (2005). Techniques of Writing Research Proposals and Reports in Education and Social Sciences. (2nd Ed). Nairobi: Kanezja HP enterprises Printers.

Partnership for Trans-Formational Devolution, Policy Brief by the PTD Partners to the $4^{\text {th }}$ Devolution Conference "Devolution-Transforming Lives: Tell Your Story." Kenya Wildlife Training Institute, Naivasha, 6th 9th March, 2017.

Paulos, C. What one hand Giveth, the other Taketh Away, Ethiopia's Post-1991 Decentralization Reform under Neo-Patrimonialism (Institute of Social Studies Printers: The Hague, 2007).

Rono C. Leah Pamela, G. S Nymusonge and Evans BiraoriOteki, 'Effectiveness of Human Resource Management on County Government Performance a Case Study for ElgeyoMarakwet County', (2015) 2 (6) International Journal of Novel Research in Interdisciplinary Studies 1-9.

Thietart, R. (2001). Doing Management Research: A Comprehensive Guide. London: Thousand Oaks Press. Zikmund, W. (2000).Business Research Methods. FortWorth Texas: Dryden Press.

Zima, H. (2007). How Intuition can be Used to Enhance Creativity in Organizations. Journal of Creative Behavior, 25, (1), 11-19. 